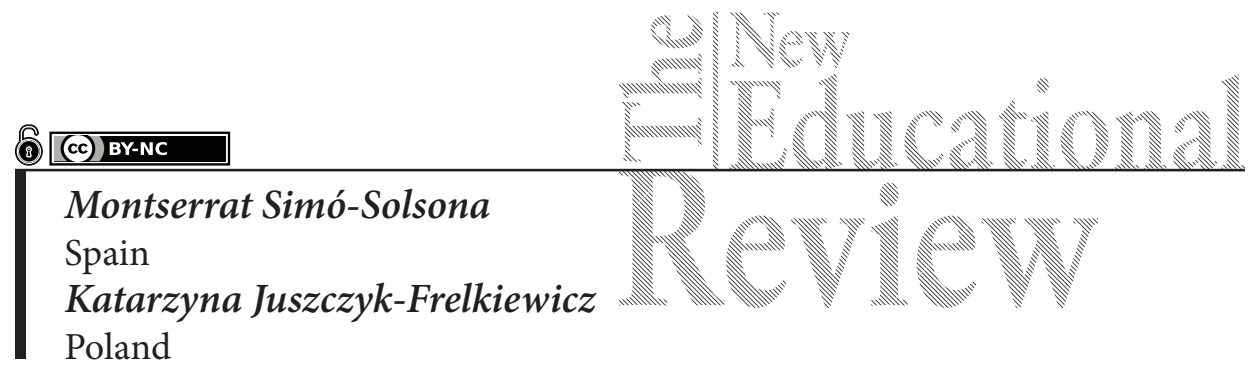

\title{
Welfare State Support for Families: a Comparative Family Policies Analysis in Poland and Spain
}

DOI: 10.15804/tner.2018.54.4.23

\begin{abstract}
The paper focuses on the analysis of recent family policies on selected programs and actions in Poland and Spain. The analysis was made on the basis of a comparison of three spheres of supporting the families in both countries: financial support, institutional support and conditions of parental leaves. The main data sources came from the OECD and Ministries in Poland and Spain. Results show that there are differences between Poland and Spain in terms of funds assigned to the support of families and children, in terms of the length of maternity and paternity leaves, the level and types of financial support, and also the types of institutional support.
\end{abstract}

Keywords: family policy, Poland, Spain, public expenditure on families, financial support for families

\section{Introduction}

Poland and Spain are currently in a very unfavourable demographic situation. According to the statistics from Eurostat (17.08.2018) in 2016, in Poland the fertility rate was 1.39 and in Spain 1.34. The level of fertility was very similar but the decreasing trends differ in time (Indexmundi, 30.06.2016). In Poland, the period of birth rate decline has lasted for over 20 years, which has caused a lack of replace- 
ment of generations. In turn, in Spain the lack of replacement of generations began almost 40 years ago (Indexmundi, 30.06.2016), even if migration has made up for these consequences. At the same time, life expectancy in Poland and Spain keeps increasing (OECD, 2018a). The lack of replacement of generations and longer life expectancy cause, on the one hand, population reduction, and on the other hand, ageing of society.

The difficult demographic situation prompts the Polish and Spanish governments to take actions to increase the number of births. In that situation, only a strategic decision taken immediately gives a chance to improve.

One example of these immediate decisions could be observed while analyzing public expenditure on families as a percentage of GDP. Comparing both countries, it seems that the total expenditure on social protection is at the same level, i.e., in Poland $16.9 \%$ and in Spain 16.8\% of GDP. Nevertheless, there are differences in the level of the distribution of these funds for supporting family and children. In the last 10 years, the Polish government has made a big effort to help Polish families. Between 2007 and 2010, the percentage of GDP in this area increased by 0.5 , as a result, in $20101.8 \%$ of GDP was spent in Poland. In turn, in 2012 a decrease to $1.6 \%$ of GDP was observed (Eurostat 08.03.2018). However, after the introduction of the Rodzina 500 plus ("Family 500 plus") financial program, the share of the state budget expenditure on family policy keeps increasing from $1.78 \%$ of GDP in 2015, 2.5\% in 2016, to $3.11 \%$ in 2017 (www.forsal.pl, 14.11.2017; Eurostat 08.03.2018). In turn, in Spain public expenditure on families was $0.7 \%$ of GDP in 2016 (Eurostat, 08.03.2018), i.e., it was even $1 \%$ of GDP less than in 2009 , which is mostly explained by economic recession consequences. It is worth noting that both countries pay a high percentage of GDP to support the elderly - Poland spent 9.1\% and Spain 9.2\% in 2016. Additionally, the Spanish government offers better support for unemployment than Poland $-1.8 \%$ and $0.5 \%$ (Eurostat, 08.03.2018), respectively.

The above data indicate that the activities and programmes of the Polish government are aimed at increasing support for families with children. In turn, in the case of Spain, support from the government reduces its range and impact - mostly after the economic recession. 


\section{Contemporary family policies in Poland and Spain}

As far as the European trend is concerned, family policies implemented after 1975 are focused on aspects that clearly link having children and the work-life balance. Improving maternity leaves, establishing benefits for employed fathers, increasing childcare services such as kindergartens and family allowances reforms are good examples (Gauthier, 1996).

The political southern family model is not only characterized by its explicit policies towards the family, but also by the type of the welfare system, the configuration of the labour market (gender biased), housing market focused on property and family-centred value system, which reinforce and reproduce it (Flaquer, 2004). For this reason, the southern family model is a completely different construct than the ones characteristic of the northern European countries, especially in terms of the combination of the above-mentioned elements (Simó-Solsona, 2017).

Poland favours the model of a two-generation family (parents and children) living in one household (GUS, 2017, p. 210). They are usually marriages with one or two children (OECD, 2011, pp. 24-25). There are also many single mothers (GUS, 2017, p. 211). Due to low fertility, delaying marriage and delaying motherhood by contemporary Polish women, who increasingly want to find fulfilment in their professional life, the Polish government offers many benefits and programs aimed at increasing fertility.

In the Long-term development strategy of the country, adopted by the Polish government, the improvement in Poland's demographic situation is considered one of the main development challenges (Council of Ministers, 2012). In the strategy, the objectives focus on the promotion of fertility by reducing the costs of care and upbringing of children, providing real support for families with three or more children and reconciling work and family life.

In contrast, the most recent Spanish family policies point out the conciliation between family and work balance, especially in the case of women, because it is undoubtedly the influence of the female activity rate, although in unbalanced conditions as compared to men. Despite this, two relevant facts have to be taken into account: on the one hand, the economic cycle that forces the welfare state to implement substantial reforms in order to stem social expenditure. But on the other, changes in the Spanish demographic profile require more social expenditure, such as ageing (clearly women and unipersonal), single-parent families and social exclusion and poverty suffered by households, affecting especially children. 


\section{Financial support for families in Poland and Spain}

Financial support for families can be divided into two main types: family benefits and tax relief'. The unresolved debate in Europe, including Spain and Poland, is whether these child benefits have to be universal or selective (means-tested). In the first case, they include an extended coverage of family income and the second ones are determined by the income level of families.

The most important financial support for families is "The Family 500 plus" program, which was introduced on the $1^{\text {st }}$ April, 2016, in Poland. The program offers untaxed PLN 500 per month for every second and subsequent child up to the age of 18 , without additional requirements. Low-income families will also receive support for the first or only child. The annual child support is PLN 6000 net (Kulczyk, 2016, p. 35). Currently, there is not any similar program in Spain².

In Poland, since the $1^{\text {st }}$ January 2013, a one-time childbirth benefit ("Becikowe") of PLN 1000 has been granted to the mother or father of a child, legal guardian or actual guardian of a child, if the family income per person does not exceed PLN 1922.00 net (Ministry of Family, Labor and Social Policy).

In the case of Spain, economic benefits for the birth or adoption of a child are not available at the national level, but only in the case of large families, single parent families and disabled mothers. Nevertheless, every region can implement additional tax relief for it. There are many differences between them, from no benefits, e.g., in Cantabria and Balearic Islands to oscillating tax relief between $€ 100-200$ for the first child (increasing the amount according to the number of children). Moreover, some regions add an economic benefit in the case of a birth in smaller cities (5000 inhabitants). Prevention of rural depopulation is a complementary objective in family policies (Spanish Tax Agency, 2018).

Another financial benefit in Poland is the supplement to the family allowance due to the beginning of the school year, which is payable once per school year in the amount of PLN 100 per child. (Ministry of Family, Labor and Social Policy).

In the case of Spain, there is no special allowance related to school at the national level. Yet, there are some economic benefits in some regions, e.g., 15\% of reduction in the kindergarten expenses until reaching the maximum of $€ 400$,

1 The first ones are child benefits to families in order to increase the disposable income. Tax relief has the same objective - to increase the purchasing power of families and they consist of reductions of specific taxes.

${ }^{2}$ Between 2007 and 2010, the government applied a family allowance of $€ 2500$ for a child without any requirements, commonly known as a "baby cheque". For further information about its effects, cf., Gonzalez (2013). 
if parents are working and their annual income is not higher than $€ 39,000$ in individual taxation (or €52,000 jointly). Tax benefits for buying school material, learning foreign languages and postgraduate studies are other examples.

The Polish government also supports single parents raising a child/children. The supplement to the family allowance for single-parent child raising is PLN 193 per month per child, but not more than PLN 386 for all children (Ministry of Family, Labor and Social Policy).

As for Spanish single-parent families, a single payment of $€ 1000$ for the birth or adoption of a child is made, when the established income limit is not exceeded $(€ 11,605.77$ for the first dependent children). Moreover, single-parent families also have some additional untaxed benefits such as a payment of $€ 291$ per year for every dependent child living at home, $€ 1000$ per year in the case of disabled children (minimum $33 \%$ of disability) and a reduction of $45 \%$ in social security taxes in the case of contracting a caregiver person (Social Security, 2018).

The next financial support is addressed to large families. The amount of the supplement to the family allowance for raising a child in Poland in a large family is PLN 95 a month. The allowance is available for the third and subsequent children entitled to family allowance (Ministry of Family, Labor and Social Policy).

Financial support for Spanish large families is comparable. There is a tax relief of $€ 1200$ per year and a double amount in the case of "especially large family" (more than 5 children) (Social Security, 2018).

In Poland, there is another family allowance, the monthly amount of which is PLN 95 per child up to the age of five, PLN 124 per child over 5 years of age up to the age of 18 and PLN 135 per child over the age of 18 up to the age of 24. The family benefit is intended to cover part of the child maintenance expenses. Granting the right to a family allowance depends on the fulfillment of the income criterion ${ }^{3}$. In Poland, there is also a supplement to the family allowance for childcare during the period of parental leave, which is PLN 400 per month as a supplement for persons entitled to a family allowance (Ministry of Family, Labor and Social Policy).

In Spain, the family allowance for raising a child at the national level is a reduction in the tax system: $€ 2800$ per year is applied, if there are children under 3.

In turn, the nationwide "Big Family Card" is a system of discounts for families with at least three or more children in Poland (Kulczyk, 2016, p. 33). Its holders have the opportunity to use the catalog of cultural, recreational or transport offers throughout the country. There is an analogous benefit in Spain. It consists of the

\footnotetext{
${ }^{3}$ Detailed rules for granting family allowances are available on the website of the Ministry of Family, Labor and Social Policy.
} 
exemption or reduction of specified taxes (i.e., academic), reduced prices in public transport and some priority access to loans and public housing.

In both countries, there are available tax systems. The Polish tax system is dependent on the level of income and the number of children. The level of income is different for married and unmarried couples and for single parents. Until 2012, the child allowance enabled the deduction of PLN 93.67 (PLN 139.01 and PLN 185.34 for the fourth and every next child) for each month of exercising parental authority (Bryndziak, 2015, p. 24).

In 2017, the Spanish tax system determined the individual and family minimum available income as $€ 5550$ per year, this amount is exempt from tax. The tax relief depends mainly on the number of children, age and a few more rules (for more cf., Spanish Tax Agency, 2018). In addition, there is tax relief related to maternity. It consists of a payment of $€ 1200$ per year from the birth or adoption day until 3 years of age Among the beneficiaries there are only working mothers, excluding unemployment and other inactive situations (Spanish Tax Agency, 2018). Valencia and Catalonia are some of the few regions that have tax relief related to the reconciliation of work and family life. In Valencia, €418 per child from 3 to 5 years of age is applied, in Catalonia there are special general benefits for parents in the case of civil servants.

\section{Contemporary institutional forms of supporting families in Poland and Spain}

The proportion of children aged $0-2$ enrolled in formal childcare and pre-school are different in Poland and Spain. According to the data from OECD (2018b), in Spain in 2014 almost $40 \%$ of children were enrolled in formal childcare and preschool - the proportion remains at a similar level between $34 \%$ and $43 \%$ over the period 2004-2014. In turn, in 2014 in Poland only 11\% of children were enrolled in nursery - it was four times less, but the tendency is increasing (cf., Table 1). The reasons for the difference can be seen in longer maternity and parental leave in Poland (52 weeks). Differences are also evident in the proportion of children aged 3-5 enrolled in pre-primary education or primary school. Nearly $97 \%$ of children in Spain attended primary school in 2013 and 2014. In Poland, it was by $20 \%$ fewer children each year (OECD, 2018b). 
Table 1. Proportion (\%) of children aged 0-5 enrolled in formal childcare and pre-school in Poland and Spain, 2004-2014

\begin{tabular}{llccccccccccc}
\hline & \multicolumn{10}{c}{ Year } \\
\hline & Country & 2004 & 2005 & 2006 & 2007 & 2008 & 2009 & 2010 & 2011 & 2012 & 2013 & 2014 \\
\hline $\begin{array}{l}\text { Children } \\
\text { aged } \\
0-21\end{array}$ & Poland & - & 7.8 & 8.8 & 9.1 & 7.8 & 7.1 & 6.9 & 8.0 & 10.9 & 9.3 & 11.0 \\
\cline { 2 - 12 } & Spain & 43.1 & 40.9 & 42.6 & 41.7 & 37.4 & 34.2 & 38.2 & 39.7 & 36.9 & 36.0 & 38.1 \\
\hline $\begin{array}{l}\text { Children } \\
\text { aged } \\
3-52\end{array}$ & Poland & n.a. & n.a. & n.a. & n.a. & n.a. & n.a. & n.a. & n.a. & n.a. & 73.2 & 74.1 \\
\cline { 2 - 12 } & Spain & n.a. & n.a. & n.a. & n.a. & n.a. & n.a. & n.a. & n.a. & n.a. & 96.6 & 96.7 \\
\hline
\end{tabular}

${ }^{1}$ Proportion (\%) of children aged 0-5 enrolled in formal childcare and pre-school.

${ }^{2}$ Proportion (\%) of children aged 3-5 enrolled in pre-primary education or primary school n.a.: not available data.

Source: own compilation based on data from OECD, 2018b.

Due to the above differences, it can be assumed that there are differences in the needs of parents or guardians in Poland and Spain with regard to the institutional forms of family support offered by the government.

Comparing the costs of childcare services, $1.7 \%$ paid the full or reduced price and an inexistent $0 \%$ used cost-free services in the case of Spain in 2016. In turn, in Poland, $10.1 \%$ paid the full or reduced price and also $0.6 \%$ cost-free service. All the numbers are far from EU-28, which for the same childcare service (under 2 years of age), $23.5 \%$ received full-paid or reduced-price childcare service and $6.0 \%$ for free (Eurostat, 24.04.18).

In Poland, there is a great need to increase the number of places for children in nurseries and kindergartens. For this reason, in 2011 the latest system of care for children aged up to 3 years began to operate and offers various types of daily care institutions, such as: nursery or children's club, as well as a daily guardian and a nanny (Report of the Council of Ministers 2017, p. 2).

It is worth mentioning that since 2016 in Poland the Ministry of Family, Labor and Social Policy has been offering a competition as part of the departmental development program for childcare institutions aged up to 3 : "MALUCH +" (Ministry of Family, Labor and Social Policy). The aim of this competition is opening more forms of care for children up to 3 years of age.

In Poland, there is also a system of care for children aged from 3 to 6 years. Children attend kindergartens, kindergarten units and other forms of pre-school education. The stay of a child in kindergarten is free of payment up to 5 hours 
a day during the core curriculum. For each additional hour parents or guardians have to pay PLN 1 (Eurydice, 2014, p. 20).

Since the $1^{\text {st }}$ of January 2017, care for children aged 6 in the kindergartens and other public pre-school education centres has been free of payment. Parents pay only for meals. This is due to the fact that 6-year-old children attending kindergartens, kindergarten units and other forms of pre-school education are covered by the educational subsidy (Ministry of National Education, 06.04.2017).

Spanish child services provision is not bad, but there is a long way to go to catch up with other European countries. The number of child services is not increasing enough parallel to the women labour market insertion. Children from 0 to 6 are included in the education system, but this period is voluntary and it is divided into two cycles: the first, from three years of age and second, until six years of age. After this age, compulsory education starts. Between 0 to 3 there are public and private nurseries. Shortage of places in public centres and the extra expenses are the main problems for families. The enrolment rate in primary education shows a constant increase from the 2005/2006 school year, except for 3-year-old children in 2014/2015. From 2005/2006 to 2010/11, the enrolment rates rose by 14.3 points in 1-year-old children and 16.7 points in 2-year-old children (Ministry of Education, Culture and Sport, 2018, p. 16). In order to complete the analysis, it would be very interesting to take into consideration out-of-school care services, mostly private.

\section{Maternity, paternity and parental leaves in Poland and Spain}

An extremely important element of the family policy are leaves related to parenthood. Existing maternity, paternity and parental leaves in Poland and Spain differ from each other, especially by the length of leaves.

The length of maternity leave in Poland, in the case of the birth of one child, is currently 20 weeks, while the parental leave is 32 weeks. Therefore, in total, there are 52 weeks of leave. Since 2013, it has been possible to use such a long leave. For a long time in Poland, there was a shorter maternity leave - 16 weeks. In 2007, the leave was longer - 18 weeks. In 2009-20 weeks. In 2010-22 weeks and in 2012-24 weeks. Thus, we observe a quite clear progress in the length of maternity leave (cf., Table 2) (OECD, 2018b). 
Table 2. Length of maternity leave in Poland and Spain

\begin{tabular}{|c|c|c|c|c|c|c|c|c|c|c|c|c|}
\hline & \multirow{2}{*}{ Country } & \multicolumn{11}{|c|}{ Year } \\
\hline & & 2006 & 2007 & 2008 & 2009 & 2010 & 2011 & 2012 & 2013 & 2014 & 2015 & 2016 \\
\hline \multirow{2}{*}{$\begin{array}{l}\text { Mater- } \\
\text { nity }\end{array}$} & Poland & 16.0 & 18.0 & 18.0 & 20.0 & 22.0 & 22.0 & 24.0 & 52.0 & 52.0 & 52.0 & 52.0 \\
\hline & Spain & 16.0 & 16.0 & 16.0 & 16.0 & 16.0 & 16.0 & 16.0 & 16.0 & 16.0 & 16.0 & 16.0 \\
\hline \multirow{2}{*}{$\begin{array}{l}\text { Pater- } \\
\text { nity }\end{array}$} & Poland & 0.0 & 0.0 & 0.0 & 0.0 & 1.0 & 1.0 & 2.0 & 2.0 & 2.0 & 2.0 & 2.0 \\
\hline & Spain & 0.4 & 2.1 & 2.1 & 2.1 & 2.1 & 2.1 & 2.1 & 2.1 & 2.1 & 2.1 & 2.1 \\
\hline
\end{tabular}

Source: own compilation based on data form OECD Family Database, 2018b.

In Spain, the length of maternity leave is only 16 weeks and since 1990 the government has not introduced any changes. We can assume that the lack of extending of maternity leave is caused by a common use of pre-school forms of childcare by parents.

In turn, paternity leave was extended in Spain in 2018, from $4^{4}$ to 5 weeks. In 2019, in the Spanish National Budget (not approved yet), paternity leave will be equal to maternity leave (16 weeks) in the next three years ${ }^{5}$. This situation allows fathers to spend more time with their children, participating in care and upbringing, although nowadays, the extent of paternity leave is residual comparing to maternity ${ }^{6}$. In Poland, paternity leave is only 2 weeks, and that leave was introduce in 2012. In 2010, there was a possibility to take only one week (cf., Table 2.) (OECD, 2018b). At present, there is no strategic governmental proposal to make the leave longer.

\section{Conclusions}

On the basis of the analysis comparing family policies in Poland and Spain, the authors systematized characteristic features of both policies, which are presented in Table 3.

The analysis shows that the Polish government has taken many actions to support Polish families, especially during the past years. The activities of the Polish

${ }^{4}$ In 2007, the Spanish government, through the approved Equality Law, extended the paternity leave from two days to 2 weeks, and it took the commitment to extend it until 4 weeks.

5 The plan is to extend the paternity leave up to 8 weeks in 2019, reaching 12 weeks in 2020 and 16 weeks in 2021 (Europa Press Madrid, 29/10/2018).

${ }^{6}$ From January to June 2018, there was $1.93 \%$ of paternity leaves among 127,348 beneficiaries (Social Security, 2018). 
government are focused, to the greatest extent, on financial support and new institutional forms of assistance. But generally, these activities are not comprehensive and also there is no long-term family policy with proper coordination. Programs supporting families are one of the points of the election campaign in Poland, that is why there is no certainty regarding the rules and the length of the operation in the future.

A long-term family policy is also absent in Spanish family policies. The main challenge is how to reconcile work and family life with more and more working mothers, part of them highly educated and not allowed to give up their professional career. Although the Spanish labour market has not recovered from the economic recession and women always have worse labour conditions than men, family policies have to encourage a changing childbirth paradigm, with a more active role of fathers participating in raising their children and assisting women who do not want to miss the "professional boat". However, until now, Spanish family policies have focused on gender issues rather than real transformation to an equal distribution of family rights.

Table 3. Comparative overview of family policies in Poland and Spain

\begin{tabular}{lll}
\hline & \multicolumn{1}{c}{ Poland } & \multicolumn{1}{c}{ Spain } \\
\hline & Fertility oriented; & Family reconciliation oriented; \\
& $\begin{array}{l}\text { Broad family models are consid- } \\
\text { ered (birth, large, single, foster, }\end{array}$ & $\begin{array}{l}\text { Broad family models are consid- } \\
\text { ered (large, single, foster, disabled } \\
\text { children and/or mother, also }\end{array}$ \\
with disabled parent and/or & divorced parents). \\
istics & children). & Influenced by the labour market.
\end{tabular}

\begin{tabular}{|c|c|c|}
\hline $\begin{array}{l}\text { Financial support } \\
\text { and relief for fami- } \\
\text { lies with children }\end{array}$ & $\begin{array}{l}\text { Means-tested (income criterion) } \\
\text { but with some universal programs. }\end{array}$ & $\begin{array}{l}\text { Means-tested; } \\
\text { Excessive priority over working } \\
\text { women than other working status. } \\
\text { Depending on tax system. }\end{array}$ \\
\hline $\begin{array}{l}\text { Institutional forms } \\
\text { of supporting } \\
\text { families with small } \\
\text { children }\end{array}$ & $\begin{array}{l}\text { Influenced by education system; } \\
\text { Not enough institutional forms but } \\
\text { more subsidized than Spain. Not } \\
\text { generalized use due to parental } \\
\text { leave. } \\
\text { Broad coverage in terms of chil- } \\
\text { dren age (until 6). }\end{array}$ & $\begin{array}{l}\text { Influenced by education system; } \\
\text { Not enough institutional forms, } \\
\text { economic benefits depending on } \\
\text { the region. } \\
\text { Reduced coverage for children } \\
\text { from } 0 \text { to } 3 \text {, broad coverage above } \\
3 \text {. }\end{array}$ \\
\hline
\end{tabular}




\begin{tabular}{|c|c|c|}
\hline & Poland & Spain \\
\hline $\begin{array}{l}\text { Parental leave con- } \\
\text { ditions }\end{array}$ & $\begin{array}{l}\text { More coverage for women than } \\
\text { men; } \\
\text { Moving to universal breadwin- } \\
\text { ner model but male breadwinner } \\
\text { predominant model. }\end{array}$ & $\begin{array}{l}\text { Mostly used by women than men; } \\
\text { Recently substantial progress in } \\
\text { order to balance maternity and } \\
\text { paternity leave (enlarge length of } \\
\text { paternity leave). } \\
\text { Moving to a universal breadwin- } \\
\text { ner but double breadwinner with } \\
\text { gender specialization predominant } \\
\text { model. }\end{array}$ \\
\hline
\end{tabular}

Source: own elaboration.

Spanish and Polish financial benefits for children can be considered meanstested. Most benefits depend on the income criterion, provided that beneficiaries do not receive another type of benefit. In Poland, the programs are more universal than in Spain - the programs in Spain address employed women to a greater extent, while other women are excluded from support. Besides, the Spanish family policies are much more influenced by the tax system.

With regard to institutional forms of supporting children, both countries need a greater number of childcare services, but facts are very different: due to maternal leave, in Spain there is greater demand for these than in Poland. However, expenses derived from childcare services are more subsidized in Poland than Spain.

Spanish parental leaves are a consequence of a more individualistic society. In this sense, these social policies contribute to establishing childbearing in more planned, negotiated and reflexive terms; breaking the traditional idea of the "only one main breadwinner". Meanwhile, maternity leave has been fixed for 16 weeks for a long time now, paternity permission is considered a "short-leave modified male-breadwinner" model (Escobedo \& Wall, 2015). Nevertheless, new recent policies are implemented by the new government. In the case of Poland, more coverage is for women than men. Although a universal breadwinner model is promoted, the male-breadwinner situation still exists, not considering enough the challenging professional ambitions of the future generations of Polish women. 


\section{References}

Bryndziak, S. (2015). Family allowance in personal income tax. In the context of tax expenditures. Research Papers Of Wrockaw University Of Economics, 403, pp. 21-29.

Council of Ministers (2014). National Development Strategy 2020. Active society, competitive economy, efficient state. Warsaw.

Escobedo, A., Wall, K. (2015). Leave policies in Southern Europe: continuities and changes. Community, Work \& Family, 18:2, 218-235. DOI: 10.1080/13668803.2015.1024822

Europa Press Madrid (2018). Los funcionarios del Estado disfrutarán de un permiso de paternidad de 16 semanas (State officials will enjoy a paternity leave of 16 weeks). $\mathrm{La}$ Vanguardia, 29/10/208 (https://www.lavanguardia.com/vida/20181029/452632546081/ funcionarios-permiso-paternidad-16-semanas.html)

Eurostat (17.08.2018). Total fertility rate. https://ec.europa.eu/eurostat/tgm/table. $\mathrm{do} ? \mathrm{tab}=$ table\&init $=1$ \&language $=\mathrm{en} \& \mathrm{pcode}=$ tps00199\&plugin $=1$

Eurostat (24.04.2018). Children receiving formal childcare services by age, income group and degree of urbanisation. http://appsso.eurostat.ec.europa.eu/nui/show.do?dataset=ilc_ ats01 \&lang=en [accessed 27.10.2018].

Eurostat (08.03.2018). government expenditure on social protection. https://ec.europa.eu/ eurostat/statistics-explained/index.php/government_expenditure_on_social_protection. [accessed 30.10.2018].

Eurydice (2014). The System of Education in Poland. Polish Eurydice Unit. Warsaw.

Flaquer, L. (2000). Is there a Southern European model of family policy? In Pfenning A., Bahle, T. (eds.). Families and Family Policies in Europe. Comparative Perspectives. Frankfurt a.m./New York: Peter Lang, pp. 15-33.

Gauthier, A.H. (1996). The State and the Family: a Comparative Analysis of Family Policies in Industrialized Countries. Oxford: Clarendond Press.

González, L. (2013) The effect of a universal child benefit on conceptions, abortions, and early maternal labor supply. American Economic Journal: Economic Policy 5 (3), 160-188.

GUS (Central Statistical Office)(2017). Statistical Yearbook of Republic of Poland 2017. Warsaw.

Indexmundi (30.06.2016). Fertility rate, total (births per woman) - country comparison - World Bank indicator. https://www.indexmundi.com/facts/indicators/SP.DYN.TFRT. $\mathrm{IN} /$ compare? country=pl\#country=pl:es.

Kowalski, A., Losz, K. (2016). Home+ programme to be introduced in Poland. https:// poland.pl/politics/home/home-programme-be-introduced-poland/

Ministry of National Education (06.04.2017). Opłaty dla dziecka 6-letniego w przedszkolu - wyjaśnienia MEN (Fees for a 6-year-old child in kindergarten - MEN explanation). https://men.gov.pl/ministerstwo/informacje/oplaty-dla-dziecka-6-letniego-w-przedszkolu-wyjasnienia-men.html

Ministry of Education, Culture and Sport (2018).Educación. Datos y cifras, Curso académico 2016-2017 (Education. Data and figures, 2016-2017 School Year). Madrid: Secretaría General Técnica. https://www.mecd.gob.es/servicios-al-ciudadano-mecd/dms/mecd/ 
servicios-al-ciudadano-mecd/estadisticas/educacion/indicadores-publicaciones-sintesis/ datos-cifras/Datosycifras1516esp.pdf

OECD (2018a). Life expectancy at birth. https://data.oecd.org/healthstat/life-expectancy-at-birth.htm [accessed 26.10.2018].

OECD (2018b). Family Database. Public policies for families and children.

https://stats.oecd.org/index.aspx?queryid=68251 [accessed 27.10.2018].

OECD (2011). Families are changing. In Doing Better for Families. pp. 17-53.

Simó-Solsona, M. (2017). Living conditions in Southern European Countries: do families cushion the impact of economic recession. In Juszczyk-Frelkiewicz, K., Libor G. (Ed.). Contemporary Family-Comparative Perspective. Publishing House of University of Silesia in Katowice. Katowice, pp. 50-69.

Social Security (2018) Otras prestaciones de la Seguridad Social. http://www.seg-social.es/ wps/portal/wss/internet/EstadisticasPresupuestosEstudios/Estadisticas/EST45

Spanish Tax Agency (2018). Deduction for maternity. https://www.agenciatributaria.es/ AEAT.internet/en_gb/Inicio/_Segmentos_/Ciudadanos/Minimos_reducciones_y_ deducciones_en_el_IRPF/Deduccion_por_maternidad/Deduccion_por_maternidad. shtml.

The report of the Council Ministers on the implementation of the Act of the $4^{\text {th }}$ of February 2011 on looking after children up to the age of 3 in 2016 (2017). Warsaw.

\section{Internet sources:}

www.forsal.pl (14.11.2017). Marczuk: wydatki z budżetu na politykę rodzinną w $2017 \mathrm{r}$. wzrosły do 3,11 proc. PKB (Marczuk: budget expenditure on the family policy in 2017 increased to $3.11 \%$ of GDP). https://forsal.pl/artykuly/1084926,marczuk-wydatki-zbudzetu-na-polityke-rodzinna-w-2017-r-wzrosly-do-3-11-proc-pkb.html. [accessed 30.10.2018].

Ministry of Family, Work and Social Policy (www.mpips.gov.pl). [accessed 27.10.2018]. 